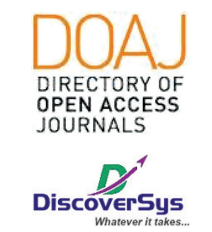

Published by DiscoverSys

\section{Gambaran profil lipid dan dislipidemia pada remaja dengan obesitas di kota Denpasar, Bali, Indonesia}

\author{
Luh Gede Yuliadewi NS, ${ }^{*}$ I Made Arimbawa
}

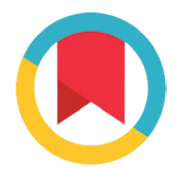

CrossMark

\title{
ABSTRACT
}

Background: Obesity results in an increase fat accumulation in the body, related to blood lipid levels, and causes dyslipidemia. Dyslipidemia is one of the main risk factors for cardiovascular events. This study aims to determine the overview of lipid profiles and dyslipidemia in adolescents with obesity in the city of Denpasar, Bali, Indonesia.

Method: A descriptive observational analytic study with a cross-sectional design was conducted on 51 obese adolescents in Denpasar using a two-stage random sampling technique. The variables assessed included examining lipid profiles such as total cholesterol, High-Density Lipoprotein (HDL), Low-Density Lipoprotein (LDL), and triglycerides. Data were analyzed with SPSS version 23 for Windows.
Results: The results showed that there were 25 male subjects (49.01\%) and 26 female subjects (50.99\%) with an average age of $15.00 \pm 3.41$ years. The mean body weight was $89.39 \pm 9.81 \mathrm{~kg}$, the mean height was $158.62 \pm 7.31 \mathrm{~cm}$, and the Body Mass Index (BMI) was $33.56 \pm 3.36 \mathrm{~kg} / \mathrm{m}^{2}$. The mean total cholesterol $170.57 \pm 25.92 \mathrm{mg} / \mathrm{dl}$, HDL $47.59 \pm$ $10.24 \mathrm{mg} / \mathrm{dl}$, LDL $113.61 \pm 26.64 \mathrm{mg} / \mathrm{dl}$, and triglycerides 126.14 (75.00) $\mathrm{mg} / \mathrm{dl}$. Dyslipidemia status based on criteria for total cholesterol levels was found in 27 subjects (52.9\%), followed by HDL (23.59\%), LDL (52.90\%), and based on triglyceride levels of $15.70 \%$ subjects. Dyslipidemia based on the overall lipid profile was found in 36 subjects (70.60\%).

Conclusions: Most subjects had total cholesterol levels above normal, HDL levels below normal, LDL levels above normal, and most subjects experienced dyslipidemia.

Keywords: Lipid Profile, Dyslipidemia, Adolescents, Obesity, Denpasar

Cite This Article:Yuliadewi N.S.L.G., Arimbawa, I.M. 2020. Gambaran profil lipid dan dislipidemia pada remaja dengan obesitas di kota Denpasar, Bali, Indonesia. Intisari Sains Medis 11(2): 629-633. D0I: 10.15562/ism.v11i2.636

\section{ABSTRAK}

Latar belakang: Obesitas mengakibatkan peningkatan akumulasi lemak berlebihan dalam tubuh, berkaitan dengan kadar lipid darah dan menyebabkan terjadinya dislipidemia. Dislipidemia merupakan salah satu faktor resiko utama untuk terjadinya kardiovaskular. Penelitian ini bertujuan untuk mengetahui gambaran gambaran profil lipid dan dislipidemia pada remaja dengan obesitas di kota Denpasar, Bali, Indonesia.

Metode: Penelitian observasioanal deskriptif dengan desain potong lintang dilakukan terhadap 51 remaja dengan obesitas di kota Denpasar menggunakan teknik two-stages random sampling. Variabel yang dinilai meliputi pemeriksan profil lipid seperti kolesterol total, High Density Lipoprotein (HDL), Low Density Lipoprotein (LDL), dan trigliserida. Data dianalisis dengan SPSS versi 23 untuk Windows.
Hasil: Hasil penelitian menunjukkan bahwa terdapat 25 subyek berjenis kelamin laki-laki $(49,01 \%)$ dan 26 subyek perempuan $(50,99 \%)$ dengan rerata usia $15,00 \pm 3,41$ tahun. Rerata berat badan $89,39 \pm 9,81 \mathrm{~kg}$, rerata tinggi badan $158,62 \pm 7,31 \mathrm{~cm}$ dan Indeks Massa Tubuh (IMT) $33,56 \pm 3,36 \mathrm{~kg} / \mathrm{m}^{2}$. Rerata kolesterol total $170,57 \pm 25,92 \mathrm{mg} / \mathrm{dl}, \mathrm{HDL} 47,59 \pm 10,24 \mathrm{mg} / \mathrm{dl}, \mathrm{LDL} 113,61 \pm 26,64$ $\mathrm{mg} / \mathrm{dl}$, dan trigliserida $126,14(75,00) \mathrm{mg} / \mathrm{dl}$. Status dislipidemia berdasarkan kriteria kadar kolesterol total didapatkan pada 27 subyek (52,9\%), diikuti dengan HDL (23,59\%), LDL (52,9\%), dan berdasarkan kadar trigliserida sebesar 15,70\% subyek. Dislipidemia berdasarkan keseluruhan profil lipid didapatkan pada 36 subyek (70,6\%).

Simpulan: Sebagian besar subyek memiliki kadar kolesterol total diatas normal, kadar HDL di bawah normal, kadar LDL di atas normal, dan sebagian besar subyek mengalami dislipidemia.
Bagian/SMF IImu Kesehatan Anak, Fakultas Kedokteran, Universitas Udayana, RSUP Sanglah, Bali, Indonesia
Kata kunci: Profil Lipid, Dislipidemia, Remaja, Obesitas, Denpasar

Cite Pasal Ini: Yuliadewi N.S.L.G., Arimbawa, I.M. 2020. Gambaran profil lipid dan dislipidemia pada remaja dengan obesitas di kota Denpasar, Bali, Indonesia. Intisari Sains Medis 11(2): 629-633. D0I: 10.15562/ism.v11i2.636

\section{PENDAHULUAN}

Obesitas telah menjadi masalah kesehatan dimana secara khusus prevalensi obesitas remaja mulai mengalami peningkatan sejak 3 dekade terakhir. ${ }^{1}$
Menurut data epidemiologi di Indonesia diperoleh bahwa angka prevalensi berat badan lebih dan obesitas pada remaja di Indonesia masih 
tinggi. ${ }^{2}$ Prevalensi berat badan lebih pada remaja usia 13-15 tahun adalah 8,3\%, sedangkan prevalensi obesitas pada remaja usia 13-15 tahun adalah 2,5\%. ${ }^{2}$ Provinsi Bali memiliki prevalensi berat badan lebih dan obesitas diatas prevalensi nasional untuk remaja usia 13-15 tahun dan usia 16-18 tahun. ${ }^{3}$

Obesitas menurut World Health Organisation (WHO) adalah suatu kondisi terjadinya akumulasi lemak berlebih dalam tubuh. ${ }^{4}$ Obesitas pada masa remaja dapat berlanjut menjadi obesitas pada masa dewasa beserta komorbidnya. ${ }^{4}$ Obesitas ditandai dengan adanya komposisi lemak tubuh yang tinggi. ${ }^{4}$ Peningkatan akumulasi lemak tubuh lebih dari $30 \%$ pada anak wanita dan lebih dari $25 \%$ pada anak lelaki dapat meningkatkan terjadinya sindrom metabolik dan meningkatkan resiko penyakit kardiovaskular meliputi hipertensi, diabetes mellitus, oleh karena itu pencegahan awitan obesitas pada usia yang lebih muda dapat mengurangi resiko penyakit kardiovaskular pada usia lanjut. ${ }^{5}$

Ukuran antropometri dan derajat obesitas berkaitan dengan kadar lemak darah atau profil lipid yang dapat menyebabkan terjadinya dislipidemia. ${ }^{6}$ Profil lipid di dalam darah terdiri dari berbagai fraksi diantaranya kolesterol total, kolesterol high densitity lipoprotein (HDL), kolesterol low densitity lipoprotein (LDL) dan trigliserida (TG). ${ }^{7}$ Dislipidemia merupakan kondisi yang mengikuti obesitas dimana terjadi gangguan metabolisme lipid yang ditandai dengan peningkatan ataupun penurunan fraksi lipid dalam plasma. ${ }^{7}$ Kelainan fraksi lipid yang utama adalah kenaikan kadar kolesterol total, trigliserida, LDL dan penurunan kadar HDL.?

Beberapa penelitian sebelumnya pada anak dengan obesitas didapatkan adanya prevalensi dislipidemia yang tinggi. Pada penelitian Tandra tahun 2014 pada siswa sekolah dasar dengan obesitas di kota Bitung didapatkan peningkatan kadar kolesterol total sebesar 26\%, kadar HDL yang rendah sebesar $62 \%$ dan peningkatan kadar trigliserida diatas nilai normal sebesar $12 \%{ }^{8}$ Penelitian Devrajani DR membandingkan profil lipid pada anak dengan obesitas dan tidak dengan obesitas didapatkan hasil 56,5\% anak dengan obesitas mengalami hiperkolesterolemia dan pada kelompok tidak obesitas didapatkan hanya 9,0\% anak dengan hiperkolesterolemia. ${ }^{9}$

Penelitian mengenai obesitas dan dislipidemia pada anak khususnya siswa sekolah dasar sudah banyak dilakukan namun data mengenai obesitas dan dilipidemia pada remaja dengan obesitas masih sangat terbatas. Berdasarkan hal tersebut maka penelitian ini bertujuan untuk mengkaji gambaran umum profil lipid dan dislipidemia pada remaja dengan obesitas di kota Denpasar, Bali, Indonesia.

\section{METODE PENELITIAN}

Penelitian ini menggunakan rancangan penelitian observasional deskriptif dengan desain potong lintang terhadap 51 remaja di Kota Denpasar. Pada remaja sebelumnya akan dilakukan pengukuran antropometri, remaja yang memenuhi kriteria obesitas kemudian akan dilakukan pemeriksaan profil lipid.

Populasi target pada penelitian ini adalah remaja usia 10 sampai 18 tahun dengan obesitas. Populasi terjangkau adalah remaja berusia 10 sampai 18 tahun dengan obesitas di kota Denpasar. Sampel penelitian adalah bagian dari populasi terjangkau, metode pemilihan sampel dengan menggunakan two stage random sampling yaitu teknik pengambilan sampel yang dipilih secara acak pada kelompok individu dalam populasi yang terjadi secara alamiah. Kriteria inklusi meliputi obesitas, usia 10 sampai 18 tahun dan terdaftar sebagai siswa SMP dan SMA di kota Denpasar. Sampel akan dieklusi bila menderita infeksi, menderita penyakit kronis, keganasan atau orang tua (wali) tidak bersedia untuk berpartisipasi dalam penelitian.

Variabel penelitian yang dinilai pada penelitian ini adalah usia, jenis kelamin, berat badan, tinggi badan, indeks masa tubuh (IMT), lingkar pinggang dan profil lipid. Usia yang dimaksudkan pada penelitian ini adalah selisih antara tanggal pemeriksaan saat dijadikan sampel dengan tanggal lahir, dinyatakan dalam tahun dengan pembulatan ke bawah bila kurang dari 6 bulan dan pembulatan ke atas bila lebih atau sama dengan 6 bulan. Jenis kelamin ditentukan dari penampakan fenotif yang dibedakan menjadi laki-laki dan perempuan. Berat badan diukur dengan menggunakan timbangan digital dengan rentang 0,1 sampai $150 \mathrm{~kg}$ dengan merk $\mathrm{Seca}^{\circledR}$ dan dicatat dengan ketelitian sampai $0,1 \mathrm{~kg}$. Pengukuran berat badan dilakukan pada sampel dengan hanya menggunakan pakaian dalam saja. Tinggi badan diukur dengan stadiometer yang memiliki penahan kepala bersudut $90^{\circ}$ terhadap stadiometer dan dapat digerakkan dengan rentang 70 sampai $200 \mathrm{~cm}$, dengan merk Seca ${ }^{\circledast}$. Pencatatan tinggi badan dengan ketelitian sampai $0,1 \mathrm{~cm}$. Indeks Masa Tubuh (IMT) didapatkan dari berat badan (dalam kg) dibagi dengan kudrat dari tinggi badan (dalam meter) menjadi $\mathrm{kg} / \mathrm{m}^{2}$. Sedangkan status obesitas dinilai apabila ditemukan IMT lebih besar dari persentil 95 pada kurva CDC 2000.

Analisis profil lipid pada penelitian ini meliputi kadar kolesterol total, trigliserida, High-Density Lipoprotein (HDL), dan Low-Density Lipoprotein (LDL) yang diperiksa dengan teknik enzimatis 
dengan alat Cobas C501. Sebelum dilakukan pengambilan darah, subyek dipuasakan minimal 12 jam dan hasil ditampilkan dalam satuan $\mathrm{mg} / \mathrm{dl}$. Parameter dislipidemia berdasarkan pada kriteria National Cholestrol Education Program (NCEP) tahun 2014 dimana diperoleh apabila kolesterol total $\geq 200 \mathrm{mg} / \mathrm{dl}$ dan/atau kadar LDL kolesterol $\geq 100 \mathrm{mg} / \mathrm{dl}$ dan/atau kadar HDL kolesterol $\leq 40 \mathrm{mg} / \mathrm{dl}$, dan/atau kadar Trigliserida $\geq 150 \mathrm{mg} / \mathrm{dl}$.

Pada seluruh data yang diperleh dilakukan entry dan analisis dengan program IBM SPSS versi 23 untuk Windows. Analisis data dilakukan analisis deskriptif untuk karakteristik sampel penelitian, disajikan dalam bentuk distribusi frekuensi, persentase, rerata dan simpang baku (SB) untuk data dengan distribusi normal dan median dan interquartil range (IQR) untuk data yang berdistribusi tidak normal.

\section{HASIL}

Pada penelitian ini, dari 4 kecamatan yang ada di kota denpasar dipilih secara acak 2 kecamatan

Tabel 1 Karakteristik sampel penelitian

\begin{tabular}{lc}
\hline Variabel & Jumlah $(\mathbf{N}=\mathbf{5 1})$ \\
\hline Jenis kelamin, $\mathbf{n}(\%)$ & \\
$\quad$ Laki-laki & $25(49,01)$ \\
$\quad$ Perempuan & $26(50,99)$ \\
Usia (Tahun) (rerata \pm SB) & $15,00 \pm 4,31$ \\
Berat badan $(\mathbf{k g})($ rerata \pm SB) & $89,39 \pm 9,81$ \\
Tinggi badan $(\mathbf{c m})($ rerata \pm SB $)$ & $158,62 \pm 7,31$ \\
Indeks Massa Tubuh $(\mathbf{k g} / \mathbf{m} 2)($ rerata $\pm \mathbf{S B})$ & $33,56 \pm 3,36$ \\
\hline
\end{tabular}

Tabel 2 Profil lipid remaja dengan obesitas di kota Denpasar

\begin{tabular}{lc}
\hline Variabel & Jumlah $(\mathbf{N}=\mathbf{5 1})$ \\
\hline Total kolesterol $(\mathbf{m g} / \mathbf{d L})($ rerata \pm SB $)$ & $170,57 \pm 25,92$ \\
HDL $(\mathbf{m g} / \mathbf{d L})($ rerata \pm SB) & $47,59 \pm 10,24$ \\
LDL $(\mathbf{m g} / \mathbf{d L})($ rerata \pm SB) & $113,61 \pm 26,64$ \\
Trigliserida $(\mathbf{m g} / \mathbf{d L})($ median $(\mathbf{I Q R}))$ & $126,14(75,00)$ \\
\hline
\end{tabular}

Tabel 3 Dislipidemia berdasarkan kadar kolesterol total, HDL, LDL dan Trigliserida

\begin{tabular}{lcccc}
\hline Kategori & Kolesterol Total & HDL & LDL & Trigliserida \\
\hline Normal, n (\%) & $24(47,10)$ & $39(76,50)$ & $24(47,10)$ & $43(84,30)$ \\
Dislipidemia, n (\%) & $27(52,90)$ & $12(23,59)$ & $27(52,90)$ & $8(15,70)$ \\
\hline
\end{tabular}

Tabel 4 Dislipidemia berdasarkan keseluruhan profil lipid

\begin{tabular}{lc}
\hline Kategori Dislipidemia & $\mathbf{n}(\%)$ \\
\hline Iya & $15(29,40)$ \\
Tidak & $36(70,60)$ \\
\hline
\end{tabular}

dengan metode cluster random sampling yaitu kecamatan Denpasar Selatan dan Denpasar Barat. Pada tiap kecamatan dipilih secara acak dua SMP dan SMA baik swasta maupun negeri. Pada penelitian ini dilakukan pemeriksaan antropometri pada 300 siswa SMP dan SMA di 8 sekolah dan sebanyak 72 anak $(24,0 \%)$ dengan status gizi obesitas berdasarkan IMT sesuai umur dan diambil 51 anak yang telah menigisi lengkap kuisioner dan mendapat persetujuan orang tua.

Pada penelitian ini dari total 51 sampel terdiri dari 25 (49,01\%) berjenis kelamin laki-laki dan 26 (50,99\%) berjenis kelamin perempuan. Berdasarkan usia, usia terendah adalah 13 tahun dan tertinggi 18 tahun dengan rerata usia 15 tahun. Rerata berat badan dan tinggi badan dari total 51 sampel masing masing sebesar $89,39 \mathrm{~kg}$ dan $158,62 \mathrm{~cm}$. Berdasarkan Indeks Masa Tubuh (IMT) didapatkan rerata 33,56 dengan simpang baku (SB) sebesar 3,36 seperti yang ditampilkan pada tabel 1 .

Tabel 2 menunjukkan gambaran kadar profil lipid pada subyek penelitian, kadar kolesterol total, HDL, dan LDL berdistribusi normal dengan rerata masing masing sebesar $170 \pm 25,92,47,59 \pm 10,24$, dan $113,61 \pm 26,64 \mathrm{mg} / \mathrm{dl}$. Kadar trigliserida memiliki distribusi data tidak normal dimana median didapatkan sebesar 126,14 mg/dl dengan interquartil range (IQR) $75 \mathrm{mg} / \mathrm{dl}$ (Tabel 2).

Kriteria dislipidemia meliputi kadar kolesterol total $\geq 200 \mathrm{mg} / \mathrm{dl}$ dan/atau kadar LDL kolesterol $\geq 100 \mathrm{mg} / \mathrm{dl}$ dan/atau kadar HDL kolesterol $\leq 40 \mathrm{mg} / \mathrm{dl}$, dan/atau kadar Trigliserida $\geq 150 \mathrm{mg} / \mathrm{dl}$. Pada penelitian ini berdasarkan kadar kolesterol total didapatkan 27 subyek $(52,9 \%)$ dengan dislipidemia, 12 subyek $(23,59 \%)$ dengan kadar HDL diatas $40 \mathrm{mg} / \mathrm{dL}$ dan $27(52,9 \%)$ subyek dengan kadar LDL diatas $100 \mathrm{mg} / \mathrm{dL}$ (Tabel 3). Untuk dislipidemia berdasarkan kadar Trigliserida didapatkan pada 8 orang subyek penelitian atau sebanyak $15,7 \%$ dari total sampel penelitian seperti yang ditampilkan pada Tabel 3.

Berdasarkan data pada Tabel 3 dimana dislipidemia ditentukan berdasarkan kriteria pada kadar kolesterol total, HDL- kolesterol, LDL- kolesterol dan Trigliserida secara terpisah, jika digunakan kriteria dislipidemia yang memenuhi ketiga kriteria untuk kadar profil lipid didapatkan hasil dari total 51 sampel penelitian 36 subyek (70,60\%) mengalami dislipidemia dan 15 subyek dengan profil lipid dalam batas normal seperti ditampilkan pada Tabel 4.

\section{PEMBAHASAN}

Pada penelitian ini didapatkan pada remaja dengan obesitas dengan jenis kelamin perempuan (50,99\%) lebih banyak dibandingkan dengan remaja 
obesitas laki-laki $(49,01 \%)$, hal ini disebabkan karena perempuan memiliki proporsi lemak tubuh yang lebih banyak jika dibandingkan dengan lakilaki, kemudian faktor hormonal juga memegang peranan penting. Penelitian yang dilakukan oleh Tuerah et al juga melaporkan hasil penelitian yang sama dimana prevalensi remaja obes perempuan lebih tinggi dibandingkan dengan laki-laki.

Kolesterol total merupakan gabungan kolesterol yang terdapat pada cholesterol-rich lipoprotein (low-density lipoprotein dan high-density lipoprotein) dan kolesterol bebas..$^{10}$ Kolesterol bebas dapat melekat pada dinding tunika intima pembuluh darah. Kolesterol kemudian akan mengalami fagositosis oleh makrofag dan berproliferasi menjadi foam cell dan mengakibatkan penyempitan pembuluh darah. ${ }^{10}$ Pada obesitas terjadi gangguan regulasi asam lemak yang akan meningkatkan ester kolesterol sehingga pada keadaan obesitas akan ditemukan kadar kolesterol darah yang lebih tinggi dibandingkan dengan individu normal. ${ }^{10}$ Peningkatan kolesterol darah juga disebabkan oleh kenaikan kolesterol yang terdapat pada very low density lipoprotein (VLDL) dan low density lipoprotein (LDL) sekunder karena peningkatan kadar trigliserida yang besar dalam sirkulasi apabila terjadi penumpukan berlebihan lemak di dalam tubuh. ${ }^{11}$ Dari hasil penelitian ini didapatkan rerata kadar kolesterol total 170,57 mg/dL dan 27 subyek (52,9\%) memiliki kadar kolesterol $\geq 200 \mathrm{mg} / \mathrm{dl}$. Hasil yang didapat pada penelitian ini lebih tinggi dibandingkan dengan yang dilaporkan pada studi oleh Rantung B et al tahun 2012 pada anak dengan obesitas di Sekolah Menengah Pertama (SMP) Swasta di kota manado yaitu $5(17,00 \%)$ dari 30 anak obes dengan kadar kolesterol total diatas $\geq 200 \mathrm{mg} / \mathrm{dL} .{ }^{12}$ Hasil yang didapatkan pada penelitian ini juga lebih tinggi dibandingkan hasil penelitian oleh Tangkilisan et al dimana terdapat 28\% siswa SMP obes dengan kadar kolesterol total abnormal. ${ }^{13}$

Pada kondisi obesitas terjadi peningkatan lemak viseral sehingga meningkatkan asam lemak bebas yang akan dibawa ke hati. ${ }^{14}$ Peningkatan asam lemak bebas ke hati ini akan meningkatkan produksi VLDL yang kaya akan trigliserida dan apoB sehingga meningkatkan kadar trigliserida dalam darah. ${ }^{14}$ VLDL kemudian akan dihidrolisis dalam darah menjadi IDL kemudian LDL yang merupakan lipoprotein dengan jumlah kolesterol terbanyak. ${ }^{4}$ Peningkatan kadar LDL akan meningkatkan kadar kolesterol darah yang menyebabkan penurunan kadar HDL yang disebabkan oleh tingginya klirens HDL untuk mengangkut kolesterol darah kembali ke hati. ${ }^{8}$ Pada penelitian ini diperoleh 12 subyek $(23,59 \%)$ memenuhi kriteria dislipidemia berdasarkan kadar HDL-kolesterol
( $\leq 40 \mathrm{mg} / \mathrm{dl}$ ), dimana hasil yang diperoleh lebih rendah dibandingkan dengan penelitian sebelumnya oleh Togelang et al dengan 51\% remaja obesitas memiliki kadar HDL-kolesterol yang rendah. ${ }^{15}$ Pada penelitian oleh Tandra et al pada remaja obesitas di kabupaten Minahasa didapatkan 100\% sampel memiliki kadar HDL-kolesterol abnormal. $^{8}$

Pada penelitian ini didapatkan 27 subyek (52,9\%) dengan kadar LDL kolesterol $\geq 100 \mathrm{mg} / \mathrm{dl}$. Hasil yang didapatkan pada penelitian ini lebih rendah jika dibandingkan dengan penelitian sebelumnya oleh Senduk et al pada siswa obesitas dengan kadar LDL-kolesterol abnormal di kota Bitung mencapai $82 \%{ }^{16}$

Trigliserida merupakan bentuk kimia dari sebagian lemak yang terdapat di dalam makanan atau di dalam tubuh. ${ }^{17}$ Trigliserida dalam plasma berasal dari lemak dalam makanan yang dikonsumsi atau diproduksi dalam tubuh yang berasal dari karbohidrat. ${ }^{17}$ Kalori yang berasal dari makanan yang tidak segera digunakan akan dikonversi menjadi trigliserida dan akan dibawa sekaligus disimpan di jaringan lemak. Trigliserida dipakai dalam tubuh untuk menyediakan energi untuk berbagai proses metabolik akan tetapi beberapa lipid, terutama kolesterol, fosfolipid dan sejumlah kecil trigliserida digunakan dalam pembentukan membran sel dan untuk melakukan fungsi sel lainnya. ${ }^{17}$ Pada kondisi obesitas akan terjadi peningkatan kadar trigliserida yang disebabkan oleh mekanisme dual metabolic defect yaitu peningkatan sekresi dan gangguan pengeluaran dari trigliseride-rich VLDL. ${ }^{17}$ Pada penelitian ini didapatkan hanya 8 subyek $(15,70 \%)$ yang mengalami dislipidemia berdasarkan kadar trigliserida. Hasil penelitian ini sama dengan hasil yang didapatkan pada penelitian Senduk et al sebelumnya dimana jika dibandingkan dengan dislipidemia berdasarkan kadar profil lipid yang lainnya, dislipidemia berdasarkan kadar trigliserida hanya ditemukan pada 3 subyek (10\%) dari total 72 sampel anak dengan obesitas. ${ }^{16}$ Hasil penelitian Senduk et al juga menunjukkan pada siswa SMP obes di Manado didapatkan 15,4\% dengan kadar trigliserida $\geq 150 \mathrm{mg} / \mathrm{dl} .{ }^{17}$

Prevalensi dislipidemia pada remaja dengan obesitas sangat tinggi, dengan menggunakan kriteria dislipidemia berdasarkan profil lipid (kadar kolesterol total, trigliserida, HDL dan LDL-kolesterol) didapatkan 70,60\% mengalami dislipidemia dan hanya $29,40 \%$ subyek dengan kadar profil lipid normal. Perubahan kadar profil lipid yang ditandai dengan peningkatan kadar kolesterol total, trigliserida, HDL dan LDL-kolesterol merupakan faktor resiko terjadinya atherosklerosis. ${ }^{4}$ Kadar LDL-kolesterol yang tinggi dan HDL-kolesterol 
yang rendah menyebabkan dinding pembuluh darah menebal sehingga terjadi penyempitan lumen pembuluh darah, hal ini dapat meningkatkan resiko penyakit kardiovaskular seperti penyakit jantung koroner dan stroke iskemik pada remaja obes yang mengalami dislipidemia. ${ }^{8}$

Hasil profil lipid yang berbeda pada penelitian ini jika dibandingkan dengan penelitian sebelumnya (hasil yang lebih tinggi untuk kolesterol total dan hasil yang lebih rendah untuk HDL dan LDL-kolesterol). Hal ini disebabkan karena pada penelitian ini tidak meneliti mengenai faktor yang mempengaruhi kadar lemak tubuh seperti jumlah dan jemis asupan makanan yang mengandung lemak, gaya hidup dan aktivitas fisik.

\section{SIMPULAN}

Sebanyak 52,9\% memiliki kadar kolesterol total diatas normal, 23,59\% memiliki kadar HDL-kolestesterol dibawah normal, 52,9\% dengan kadar LDL-kolesterol diatas normal dan 15,7\% dengan kadar trigliserida diatas normal. Sebanyak $70,6 \%$ subyek penelitian diketahui mengalami dislipidemia.

\section{KONFLIK KEPENTINGAN}

Tidak terdapat konflik kepentingan dalam penulisan laporan penelitian ini.

\section{ETIKA PENELITIAN}

Penelitian dan keterangan kelayakan etik penelitian ini diberikan oleh komisi Etika Penelitian Fakultas Kedokteran Universitas Udayana RSUP Sanglah Denpasar dengan nomor ethical clearance 600/ UN.14.2/KEP/2017.

\section{PENDANAAN}

Tidak ada.

\section{KONTRIBUSI PENULIS}

Seluruh penulis memiliki kontribusi yang sama dalam penulisan laporan penelitian ini baik dari penyusunan kerangka konsep, pengumpulan data, analisis data, hingga interpretasi data penelitian dalam bentuk publikasi.

\section{DAFTAR PUSTAKA}

1. Bibiloni Mdel M, Pons A, Tur JA. Prevalence of overweight and obesity in adolescents: a systematic review. ISRN Obes. 2013;2013:392747.

2. Pengpid S, Peltzer K. The Prevalence of Underweight, Overweight/Obesity and Their Related Lifestyle Factors in Indonesia, 2014-2015. AIMS Public Health. 2017;4(6):633-649.

3. Priliani L, Oktavianthi S, Hasnita R, Nussa HT, Inggriani RC, Febinia CA, et al. Obesity in the Balinese is associated with FTO rs9939609 and rs1421085 single nucleotide polymorphisms. PeerJ. 2020;8:e8327.

4. Lobstein T, Baur L, Uauy R; IASO International Obesity TaskForce. Obesity in children and young people: a crisis in public health. Obes Rev. 2004;5 Suppl 1:4-104.

5. Vega GL. Obesity and the metabolic syndrome. Minerva Endocrinol. 2004;29(2):47-54.

6. Vekic J, Zeljkovic A, Stefanovic A, Jelic-Ivanovic Z, Spasojevic-Kalimanovska V. Obesity and dyslipidemia. Metabolism. 2019;92:71-81.

7. National Cholesterol Education Program (NCEP) Expert Panel on Detection, Evaluation, and Treatment of High Blood Cholesterol in Adults (Adult Treatment Panel III). Third Report of the National Cholesterol Education Program (NCEP) Expert Panel on Detection, Evaluation, and Treatment of High Blood Cholesterol in Adults (Adult Treatment Panel III) final report. Circulation. 2002;106(25):3143-3421

8. Tandra HJR, Fatimawali, Kepel B. Prevalensi obesitas dan Profil Lipid pada remaja di Kabupaten Bitung. Jurnal e-Clinic 2014;2(2):71-5.

9. Devrajani DR, Artigas A, Brigham KL, Carlet J, Falke K, et al. The India Consensus on Obesity. Obesity and Dislipidemia. 2004;149:818-24.

10. Lennon DL, Stratman FW, Shrago E, et al. Total cholesterol and HDL-cholesterol changes during acute, moderate-intensity exercise in men and women. Metabolism. 1983;32(3):244-249.

11. Bibiloni MD, Salas R, De la Garza YE, Villarreal JZ, Sureda A, Tur JA. Serum Lipid Profile, Prevalence of Dyslipidaemia, and Associated Risk Factors Among Northern Mexican Adolescents. J Pediatr Gastroenterol Nutr. 2016;63(5):544-549.

12. Rantung B, Bodhi W, Kepel B. Gambaran profil lipid pada remaja obes di Kota Manado. Jurnal e-Biomedik. 2012;2(4):22-7.

13. Tangkilisan AH, Akune K. Some factors related to lipid profile in obese children at junior high schools in Manado. 2007;47(4):166-171.

14. Ebbert JO, Jensen MD. Fat depots, free fatty acids, and dyslipidemia. Nutrients. 2013;5(2):498-508.

15. Togelang L, Fatimawali, Manampiring A. Gambaran kadar High Density Lipoprotein pada Remaja Obes di Kabupaten Minahasa. Jurnal e-Biomedik. 2013;1(4)45-50.

16. Senduk BD, Satya WP, Ikhan PD. Gambaran profil lipid pada remaja obes di Kota Bitung. Jurnal e-Biomedik. 2012;4(1):52-7

17. Laufs U, Parhofer KG, Ginsberg HN, Hegele RA. Clinical review on triglycerides. Eur Heart J. 2020;41(1):99-109c.

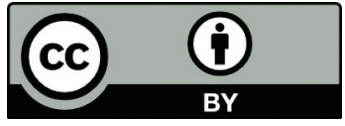

This work is licensed under a Creative Commons Attribution 